\title{
High-throughput Analysis of CircRNA in Cows with Naturally Infected Staphylococcus aureus Mammary Gland
}

\section{Research Article}

Keywords:

Posted Date: March 23rd, 2022

DOI: https://doi.org/10.21203/rs.3.rs-659273/v2

License: (c) (1) This work is licensed under a Creative Commons Attribution 4.0 International License. Read Full License 


\section{Abstract}

The full text of this preprint has been withdrawn by the authors in order to comply with an institutional policy on preprints. Therefore, the authors do not wish this work to be cited as a reference.

\section{Full Text}

The authors have withdrawn this preprint from Research Square. 